\title{
Digital Modernization of the System of Public Administration: Prerogatives and Barriers
}

\author{
Sayabek Ziyadin ${ }^{1, *}$, Khakimzhan Malayev ${ }^{1}$, Igor Fernández-Plazaola ${ }^{2}$, Gulim Ismail $^{1}$, \\ Anara Beyzhanova ${ }^{1}$, \\ ${ }^{1}$ Al-Farabi Kazakh National University, al-Farabi Ave. 71, 050040 Almaty, Republic of Kazakhstan \\ ${ }^{2}$ Universitat Politècnica de València, 46022, Valencia, Spain
}

\begin{abstract}
In most advanced countries of the world, the transition of public administration to "digital tracks" is proceeding rather slowly; development is far behind officially defined and announced schedules. In this regard, the digital modernization of the public administration system becomes particularly relevant. The purpose of the article is to identify the prerogatives for digital modernization of the public administration system, based on an assessment of the development of digital government and identification of major barriers. Based on the assessment, a high level of development of the digital government in Kazakhstan has been determined, despite the special emphasis of government agencies on automation in recent years, the visible results of the conversion of public services into electronic format are still unsatisfactory. The article discusses the main barriers and prerogatives of digital modernization of the public administration system. The authors conclude that active digital modernization of the public administration system implies the expansion of methods for analyzing and evaluating the implementation of government programs and projects, including the audit of the effectiveness and efficiency of their implementation.
\end{abstract}

\section{Introduction}

The World Economic Forum (WEF) estimates that digitalization has great potential for business and society, and could generate an additional $\$ 30$ trillion in revenue for the global economy over the next 10 years [1]. In addition, according to the forecasts of the international research company IDC, $40 \%$ of the leading companies can be squeezed out of the market by newcomers who from the very beginning embarked on the digital path [2]. This shows that digital transformation is one of the strategic directions of economic modernization.

The implementation of key tasks of the country's social and economic development is inextricably linked to the successful introduction of digital technologies into management,

\footnotetext{
* Corresponding author: sayabekz@gmail.com
} 
social and business processes. However, these seemingly obvious goals cannot be achieved outside the digitalization of public administration.

The modernization of the public administration system in Kazakhstan is carried out from the moment of gaining sovereignty and continues to this day. In 2017, a constitutional reform was carried out aimed at the redistribution of powers between the branches of state power. The role of Parliament and its control over the Government have been strengthened. A "compact Government" is being formed, responsible to citizens. Some functions and services are transferred to lower levels and to the competitive environment. The principles of meritocracy, a new system for evaluating civil servants, are being introduced in the public service. Over the past five years, the effectiveness of government agencies has grown by $25 \%$, and the population's satisfaction with the quality of public services has grown by $20 \%$ only in the last two years, according to the assessment for 2014-2015. Nevertheless, in 2015, the index of government performance, according to the World Bank, amounted to 41 points out of 100 , while a group of 30 developed countries has indicators from 75 points [1].

Despite the results achieved, problems associated with an insufficient level of openness, customer focus and proactivity remain relevant. The current system does not encourage innovation, as a result of which successful changes in the work of public authorities are targeted and not widespread. Control mechanisms prevail that stimulate orientation on the process, not on the result.

Thus, we can conclude that the modernization of public administration in the Republic of Kazakhstan requires a search for new conceptual approaches and methods that take into account global trends and innovations in public administration.

The purpose of the research is to identify the prerogatives for digital modernization of the public administration system, based on an assessment of the development of digital government and identification of major barriers.

\section{Literature review}

In order to organize digital interaction between government authorities and its various branches, citizens, public organizations, and business, a complex of information technologies, the Internet, and mobile technologies is being created, which was previously called electronic government. The term "electronic government" (e-government) became widely known at the turn of the 1990s and 2000s, when ICTs began to be introduced into the political sphere of society on a massive scale, and it was immediately linked to hopes for modernization of the nature of interaction between government and society. However, over two decades, work on e-government has been reduced mainly to the online provision of public services. Only recently, with the advent of new digital technologies, has the digital government begun to be talked about again as a revolutionary new way for authorities and citizens to interact with each other. In this case, digital government understood not as a set of isolated systems for delivering public services, but as a whole connected ecosystem, where data and processes are exchanged electronically, enabling direct interaction between authorities and citizens.

There are many definitions of the term "digital government". The term digital government first appeared in the middle of 1990s under President B. Clinton as the idea of systematic introduction and use of modern ICTs in the activities of government agencies to improve the efficiency and transparency of the state apparatus [3]. Initially, the most ambitious tasks were set for digital government: "instead of a hierarchical, sedentary and closed management system, flexible, horizontally connected structures should appear that operatively interact with each other, open for control at any link and quickly and efficiently interact with citizens" [4]. 
The concept of digital government has quickly become global. The issue placed on the agenda of the World Summit on the Information Society (WSIS) organized by the United Nations, and World Bank has taken up its implementation in developing countries (the website of which has a special section on e-government). Researchers describe the concept of "digital government" in different ways, focusing on its various aspects (Table 1). is

Many researchers are of the opinion that, in its most general form, digital government

the theory and practice of building a direct (governing) and reverse (controlling) relationship between local and public authorities on the one hand, and citizens, their associations (commercial and non-profit, public organizations), on the other hand, through the broad possibilities of digital technology.

Table 1. Developing definitions and concept of digital government.

\begin{tabular}{|c|c|}
\hline Sources & Definition \\
\hline $\begin{array}{l}2001 \text { Benchmarking E- } \\
\text { government: } \\
\text { A Global Perspective [5] }\end{array}$ & $\begin{array}{l}\text { E-government is 'a tool for information and service provision to } \\
\text { citizens'. }\end{array}$ \\
\hline $\begin{array}{l}2003 \text { World Public Sector } \\
\text { Report: E-Government at } \\
\text { the Crossroads [6] }\end{array}$ & $\begin{array}{l}\text { E-government enhances the capacity of public administration using } \\
\text { ICTs to increase the supply of public value (i.e., to deliver the } \\
\text { things that people want). }\end{array}$ \\
\hline 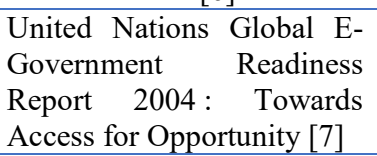 & $\begin{array}{l}\text { E-government is defined as the use of all ICTs by government to } \\
\text { provide information and services to the public. This is a broader } \\
\text { concept than in cases where it refers only to G-2-G networking. }\end{array}$ \\
\hline $\begin{array}{ll}\text { United Nations } & \text { Global E- } \\
\text { Government } & \text { Readiness } \\
\text { Report 2005: From E- } \\
\text { Government to E-Inclusion } \\
\text { [8] }\end{array}$ & $\begin{array}{l}\text { The definition of e-government needs to be enhanced from simply } \\
\text { 'government-to-government networking' or 'use of ICTs by } \\
\text { governments to provide information and services to the public' to } \\
\text { one which encompasses the role of the government in promoting } \\
\text { equality and social inclusion. }\end{array}$ \\
\hline $\begin{array}{l}\text { United Nations E- } \\
\text { Government Survey 2008: } \\
\text { From E-Government to } \\
\text { Connected Governance [9] }\end{array}$ & $\begin{array}{l}\text { E-government is the continuous innovation in the delivery of } \\
\text { services, public participation and governance through the } \\
\text { transformation of external and internal relationships using } \\
\text { information technology, especially the Internet. }\end{array}$ \\
\hline $\begin{array}{l}\text { UN E-Government Survey } \\
\text { 2014: E-Government for the } \\
\text { Future We Want [10] }\end{array}$ & $\begin{array}{l}\text { E-government can be referred to as the use and application of } \\
\text { information technologies in public administration to streamline and } \\
\text { integrate workflows and processes, to effectively manage data and } \\
\text { information, enhance public service delivery, as well as expand } \\
\text { communication channels for engagement and empowerment of } \\
\text { people. }\end{array}$ \\
\hline $\begin{array}{l}\text { Organisation for Economic } \\
\text { Cooperation and } \\
\text { Development [11] }\end{array}$ & $\begin{array}{l}\text { E-government is defined as 'the use of information and } \\
\text { communications technologies (ICTs), and particularly the Internet, } \\
\text { to achieve better government'. }\end{array}$ \\
\hline $\begin{array}{l}\text { Digital Government and } \\
\text { Open Data Readiness } \\
\text { Assessment [12] }\end{array}$ & $\begin{array}{l}\text { Digital government is recognized as a key initiative towards public } \\
\text { administration reform and an increased transparency while it is also } \\
\text { time-saving, cost efficient, and minimizing effort for both the } \\
\text { government and users (citizens). }\end{array}$ \\
\hline $\begin{array}{l}\text { Sundberg, L. } \quad[13] \text {; } \\
\text { Twizeyimana, J. D., \& } \\
\text { Andersson, A. [14]; Liu, D., } \\
\text { \& Carter, L. [15] }\end{array}$ & $\begin{array}{l}\text { Electronic government (e-Government) is a research field that } \\
\text { studies the use of information and communication technology } \\
\text { (ICT) in the public sector. }\end{array}$ \\
\hline $\begin{array}{l}\text { Abu-Shanab, E., \& Al- } \\
\text { Azzam, A. [16]; Dias, G. P. } \\
\text { [17] }\end{array}$ & $\begin{array}{l}\text { E-government is defined as the use of ICT tools and applications to } \\
\text { provide better services to citizens and businesses. }\end{array}$ \\
\hline
\end{tabular}


Choi, T., \& Chandler, S. M. [18]; Liang, Y., Qi, G., Zhang, X., \& Li, G. [19]

Lindgren, I., Madsen, C., Hofmann, S., \& Melin, U. [20], Faulkner, N., Jorgensen, B., \& Koufariotis, G. [21]

Summarizing the opinions of scientists, we can conclude that, digital government is an open, transparent and convenient opportunity for citizens and businesses, available online and at any time. Despite the presence of scientific interest in the study as a whole, currently the unresolved part is the problem of matters of digital modernization of the system of public administration. On this basis, there is a need for a more detailed research of the barriers in digital modernization of the public administration system and the identification of its main trends, since the lack of knowledge and lack of systematization of directions creates certain difficulties in the modernization process.

\section{Data and methodology}

\subsection{Methodology for UN e-Government Index ranking}

A number of organizations, ranging from the UN Department of Economic and Social Affairs to a number of influential academic institutions (such as Waseda University of Tokyo or Taubman Center for Public Policy at Brown University) measure the ratings of egovernment development in countries around the world.

The UN determines the degree of countries' progress towards e-government using the EGovernment Development Index (EGDI). The E-Government Development Index (EGDI) identifies, highlights and weighs the conditions of the e-government functioning environment, which ensures that any group of the country's population has access to public information and government services that people need. The results of the ranking of countries in the e-Government Readiness Index is very much related to the level of economic, social and democratic development.

From a mathematical point of view, the e-Government Development Index (EGDI) is a weighted average of normalized indicators for the three main aspects of e-government [22]:

(i) the volume and quality of online services, expressed as an online service index $(O S I)$;

(ii) the status of telecommunication infrastructure development or telecommunication infrastructure index (TII);

(iii) domestic human capital or human capital index (HCI).

Each of these indices is a composite indicator that can be extracted for independent analysis.

$$
E G D I=\frac{1}{3}\left(O S I_{\text {normalized }}+T I I_{\text {normalized }}+H C I_{\text {normalized }}\right)
$$

where: normalization of each indicator is carried out according to the rule $x_{\text {normalized }}=$ $(x-\mu) / \delta, \mu$-average sample from all countries, $\delta$ - sampling standard deviation from all countries.

The composite value of each component index is then averaged to a range from 0 to 1 , and the total EGDI value is determined as the arithmetic mean of the three component indices. 


\subsection{Evaluation of Digital Government Development in Kazakhstan}

Over the last 17 years since the UN first attempt to note the state of e-government in 2001, it has evolved rapidly. The 2018 study highlights the continuing positive global trend of egovernment development. In 2018, 40 countries were rated "very high", with EGDI values between 0.75 and 1 . By comparison, there were only 10 such countries in 2003 and only 29 in 2016. Since 2014, all 193 Member States have had some form of online presence. Figure 1 shows the percentage ratios of EGDI groups for 2018 and 2016.
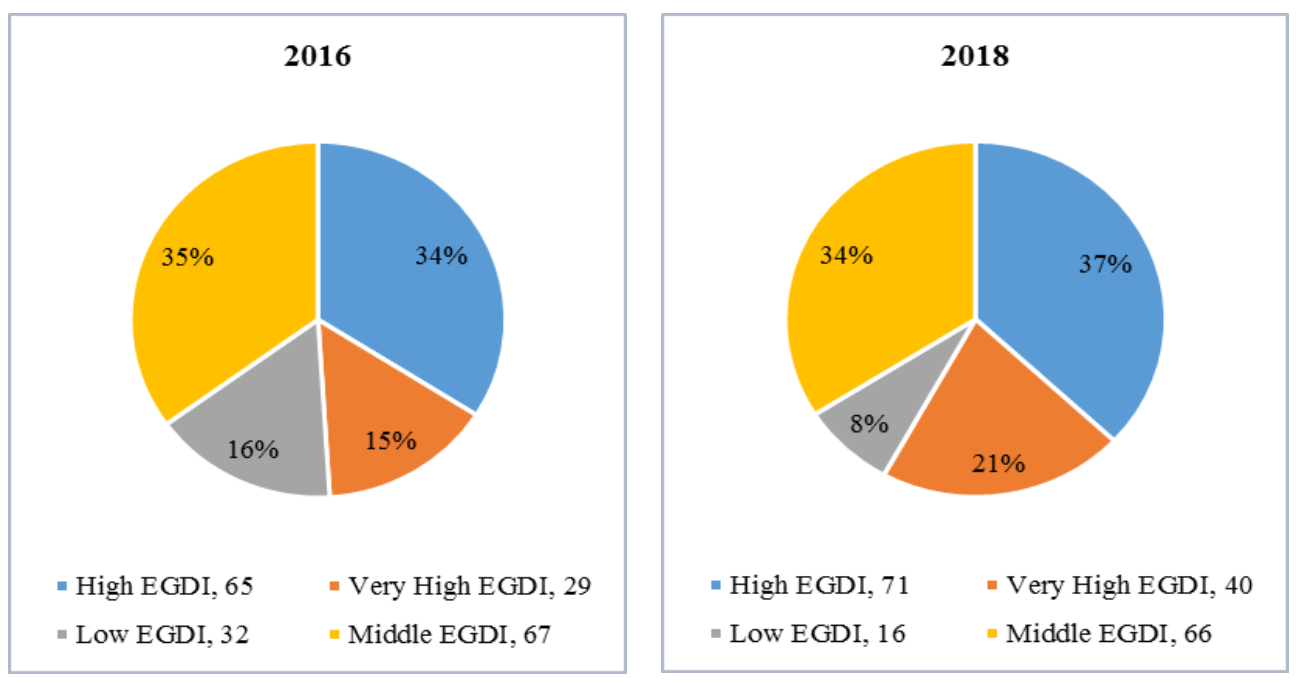

Fig. 1. Number of countries grouped by E-Government Development Index (EGDI) in 2016 and 2018 [22].

In 2018, the number of countries with high and very high EGDI or values between 0.50 and 1.00 has increased. The share of countries in the high and very high EGDI groups increased by 3 and 6 percent respectively. As a result, the percentage of countries with high and very high levels of e-government development has cumulatively reached 58 per cent or almost two thirds of the total number of UN Member States.

According to the latest UN "E-Government Survey 2018" report [22], Kazakhstan ranked $39^{\text {th }}$ with a value of 0.7597 (Figure 2). The first three places in the ranking were taken by Denmark, Australia and South Korea. 


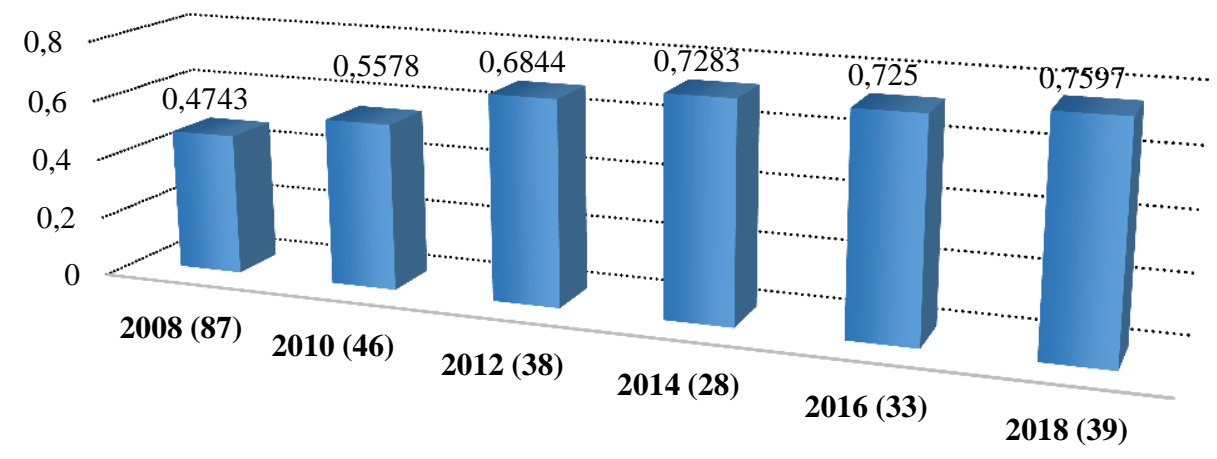

Fig. 2. Dynamics of change in the position of the Republic of Kazakhstan in the rating of egovernment development, 2008-2018 [22].

According to the UN report for 2018, Kazakhstan's online services sub-index increased from 0.7681 to 0.8681 , telecommunication infrastructure sub-index increased from 0.5668 to 0.5723 , and human capital sub-index decreased from 0.8401 to 0.8388 (Table 2).

Table 2. Top 10 countries for e-government - Landlocked Developing Countries [22].

\begin{tabular}{l|c|c|c|c|c|c|c|c}
\hline \multicolumn{1}{c|}{ Country } & Region & Sub-Region & OSI & HCI & TII & EGDI & $\begin{array}{c}\text { EGDI } \\
\text { Level }\end{array}$ & $\begin{array}{c}\mathbf{2 0 1 8} \\
\text { Rank }\end{array}$ \\
\hline Kazakhstan & Asia & Central Asia & 0.8681 & 0.8388 & 0.5723 & 0.7597 & Very High & 39 \\
\hline Moldova & Europe & Eastern Europe & 0.7708 & 0.7274 & 0.4787 & 0.6590 & High & 69 \\
\hline Azerbaijan & Asia & Western Asia & 0.7292 & 0.7369 & 0.5062 & 0.6574 & High & 70 \\
\hline Macedonia & Europe & Southern Europe & 0.7153 & 0.6924 & 0.4859 & 0.6312 & High & 79 \\
\hline Uzbekistan & Asia & Central Asia & 0.7917 & 0.7396 & 0.3307 & 0.6207 & High & 81 \\
\hline Armenia & Asia & Western Asia & 0.5625 & 0.7547 & 0.4660 & 0.5944 & High & 87 \\
\hline Kyrgyzstan & Asia & Central Asia & 0.6458 & 0.7628 & 0.3418 & 0.5835 & High & 91 \\
\hline Mongolia & Asia & Eastern Asia & 0.5972 & 0.7899 & 0.3602 & 0.5824 & High & 92 \\
\hline Bolivia & Americas & South America & 0.5625 & 0.7148 & 0.3148 & 0.5307 & High & 103 \\
\hline Paraguay & Americas & South America & 0.5556 & 0.6701 & 0.3507 & 0.5255 & High & 108 \\
\hline
\end{tabular}

Despite the results achieved, there are still problems associated with a lack of openness, customer focus and proactivity. The emergence of new technologies makes it possible to provide services of higher quality than those currently implemented. For example, the use of big data technologies may lead to a fundamentally new approach to analyzing the needs of the population, and as a result, to improve the quality of service.

\subsection{Barriers of digital modernization of the public administration system}

The modern world economy is presented as an economy of the "new technological generation" [23]: it involves the development of super-modern "through technologies" such as artificial intelligence, blockchains and big data, in professional fields and everyday life [24]. Digital, mobile, virtual technologies involve users of different degrees of readiness, but in this process there are always barriers and difficulties - be it physical obstacles and lack of access, material resistance and obsolescence of infrastructures or human fear. 
Political will, market mechanisms and a high level of information technology development are not sufficient for digitalization to be effective at all.

Recently, innovative technologies have been actively introduced in all sectors [25]. In conjunction with digital innovation, technological, sociocultural and institutional barriers arise. Lack of access to the Internet and hardware, such as computers, phones and mobile devices, was once considered a digital barrier. Technological advances and availability, such as mobile phones, have corrected this situation. However, new digital barriers have emerged, such as the speed and quality of these devices, as well as digital literacy or the ability to use them. Therefore, instead of a single digital barrier, a multitude has formed. This is not only a global problem, but also a local one, related to certain circumstances, if we talk about the availability of resources, bandwidth and skills. Table 3 shows a set of digital barriers to digital modernization of the public administration system.

Table 3. Barriers of digital modernization of the public administration system [22].

\begin{tabular}{|c|c|}
\hline Barriers & Description \\
\hline Access & $\begin{array}{l}\text { It starts with access or the lack thereof: although Internet penetration has } \\
\text { increased, it continues to be a key barrier, as more people globally remain } \\
\text { offline rather than online. }\end{array}$ \\
\hline Affordability & $\begin{array}{l}\text { The gap between rich and poor affects the affordability of ICT and is an } \\
\text { important indicator that shows the difference in technology adoption } \\
\text { between regions within a country and between countries. }\end{array}$ \\
\hline Age & $\begin{array}{l}\text { Older people are generally using ICTs to a lesser extent than younger } \\
\text { populations, despite the notion that they could benefit from online social } \\
\text { and health services. }\end{array}$ \\
\hline Bandwidth & $\begin{array}{l}\text { International bandwidth and the ability to transmit and receive information } \\
\text { over networks varies greatly from country to country and from region to } \\
\text { region, thus limiting potential useful ventures. }\end{array}$ \\
\hline Content & $\begin{array}{l}\text { Appropriate resources in the local language(s) are needed to encourage } \\
\text { implementation. }\end{array}$ \\
\hline Disability & $\begin{array}{l}\text { Individuals with disabilities face additional barriers when using ICTs if } \\
\text { websites do not follow accessibility guidelines. }\end{array}$ \\
\hline Education & $\begin{array}{l}\text { Like social inequalities, education and literacy are among the fundamental } \\
\text { issues that need to be addressed to overcome digital divides. }\end{array}$ \\
\hline Gender & $\begin{array}{l}\text { There is a small but persistent difference in internet usage between men } \\
\text { and women. }\end{array}$ \\
\hline Migration & $\begin{array}{l}\text { The level of digital skills of migrants may lag behind the population in } \\
\text { their new country and, if so, resource- and language-based divisions may } \\
\text { arise. }\end{array}$ \\
\hline Location & $\begin{array}{l}\text { Rural and remote areas are often at a disadvantage in terms of speed and } \\
\text { quality of services compared to their urban counterparts. }\end{array}$ \\
\hline Mobile & $\begin{array}{l}\text { Mobile devices can bridge the access gap, but can also create new barriers } \\
\text { in terms of technology, speed and usage. }\end{array}$ \\
\hline Speed & $\begin{array}{l}\text { The gap between basic and broadband access creates a new barrier, as } \\
\text { speed is important to get all the benefits of the digital society. }\end{array}$ \\
\hline Useful usage & $\begin{array}{l}\text { What people do with their access is a key difference in whether users take } \\
\text { full advantage of ICTs, such as e-government services. }\end{array}$ \\
\hline
\end{tabular}

Meeting the needs of the poorest and most vulnerable groups is one of the prerequisites for sustainable and flexible societies. Given today's complexities - from humanitarian crises and migration processes to urban and rural poverty issues - technology makes it possible to reach everyone, increasing access to information and services for those who need them most. 


\section{Results and discussion}

Despite the special emphasis of government agencies on automation in recent years, the visible results of the conversion of public services into electronic format are still unsatisfactory. Thus, if at the beginning of $201860 \%$ (or 447 out of 746) of services were available to the population through the web portal of "e-government", the real volume of public services received through the portal amounted to only $18.7 \%$ of the total volume (28.5 million out of 152.6 million), with half of them accounted for address information.

A number of public services, despite the availability on the portal, were received mainly by the public authorities. Thus, services for making an appointment and calling a doctor at home are not popular enough on the portal (only $6 \%$ is provided through the portal), which are usually provided through telephone and manual recording of patient data in the information systems. This does not exclude the human factor, implies labor costs on both sides and contradicts the principles of automation. The same situation with the service of admission of documents and enrollment in school $-84 \%$ of the total volume of this public service was provided in paper form.

The low popularity of the web portal "e-government" may have been due to technical problems and difficulties in working on the portal. In the media and social networks, as well as in the framework of public monitoring, there are regular technical failures and procedural difficulties in the authorization on the portal using Electronic Digital Signature (EDS). The core activities of government agencies are automated - however, there are still areas of activity that are not sufficiently covered by informatization. The emergence of new technologies makes it possible to provide services of higher quality than those currently implemented.

In general, the digital modernization of the public administration system has a positive impact on compliance with a number of public administration principles. Thus, the introduction of digital government has a positive impact on the balance of interests of all stakeholders, the balance of interests of present and future generations, the balance of proactive and reactive approaches to public policy, the balance of personal responsibility for the result and freedom of administration (Table 4).

Table 4. Prerogatives of digital modernization of the public administration system

\section{Principles of public administration}

Balance of interests of all Digital modernization creates conditions for more complete stakeholders

\section{Assessment of the impact of digital modernization} compliance with this principle, including at the stage of planning, monitoring and evaluation of public policy results, creates new forms of data collection and processing that reflect the interests of all stakeholders, including data collection in the passive mode (through analysis of social networks, search engines, etc.).

Balance of interests of present Digital modernization is generally neutral with respect to the and future generations implementation of this principle (digital technologies can be used both for the research of problems of a strategic nature and for tactical purposes).
Balance of expected results and available resources

Digital modernization of the public administration system as a whole has a positive impact on compliance with this principle, both through the introduction of special tools to substantiate ICT projects (business cases) and through the collection and analysis of detailed information on transaction costs of public authorities and, consequently, the possibility of optimizing these costs.

Balance of initiative and assessment of achievements:
In general, digital modernization creates the conditions for more complete implementation of this principle, including by 
a combination of proactive and reactive approaches

Balance of personal responsibility for results and freedom of administration providing tools for early problem identification (including the use of artificial intelligence) and proactive solutions.

Digital modernization enhances accountability for results by expanding the data sources that can be used for monitoring and evaluation.

Source: composed by authors

Thus, it can be concluded that digital modernization of the public administration system contributes to achieve the following objectives:

- reduction of expenses on the activities of government agencies - through optimization of supporting, invariant functions (back offices of government agencies);

- increasing the productivity of civil servants in the provision of public services and the implementation of control and supervision activities - through the standardization and modernization of administrative and managerial processes;

- reducing the cost of creation and administration of information resources and systems - through the reuse of information technologies and services;

- improving the efficiency of budget expenditures on program (project) activities implemented by the authorities - through promoting and stimulating the introduction of digital technologies in sectors of the economy;

- increasing the level of trust of citizens and business to the authorities and officials, supporting their decisions (policies) - through the formation of an ecosystem of public and private platforms.

While researching this topic, we have also considered the impact of the relationship between global socio-economic indicators on human development. Digitalization can also influence the testing of average price reversals for agricultural products. Factors such as overdue debt and individual personality traits can also change the situation [26, 27,28,29].

\section{Conclusion}

Digital modernization of the public administration system is one of the tasks of the state policy of the Republic of Kazakhstan. Transforming the world and achieving sustainable development goals until 2030 requires a paradigm shift in public self-governance. This requires a rethinking of the role of the State and its interaction with civil society and the private sector in performing public functions in the country and responding to people's needs. ICTs and digital government can ensure that everyone is included in sustainable development. The 2030 Agenda explicitly recognizes the vital role of these two components as a catalyst for the realization of this vision and states that "the diffusion of information and communication technologies, as well as global collaboration, have great potential to accelerate progress, remove digital barriers, and develop knowledge societies through, for example, scientific and technological innovation development in various fields".

Active digital modernization of the public administration system implies the expansion of methods for analyzing and evaluating the implementation of government programs and projects, including the audit of the effectiveness and efficiency of their implementation. To date, performance evaluation is often reduced to calculating the degree of achievement of the target values of indicators of program and project implementation, and monitoring is based on an assessment of the proportion of key events (activities) that have occurred in a timely manner or with violations of time. The use of technologies of predictive analytics, artificial intelligence would significantly change the quality of analytics used in government administration and, consequently, the quality of information and analytical support of decisions. Thus, technologies of processing of "big data" allow to reveal new 
interrelations between various parameters and to adapt state policy measures to the needs and features of addressees of regulation. The involvement of unstructured and partially structured data in the analysis of the consequences of policy implementation, in the assessment of the problems that regulation is aimed at solving and the formation of goals that it must achieve, will improve the validity of decision-making. Moreover, to consider individual alternatives in decision-making, as well as to conduct a deeper and more qualitative analysis of the consequences of the implementation of certain decisions, projects, initiatives. Already today, such an analysis using digital technologies can be carried out both ex ante (including on the basis of controlled sample studies, "testing of regulation" using social networks and assessment of the effectiveness of proposed measures) and ex post (including on the basis of various sets of "big data" and their processing by artificial intelligence).

Digitalization does not depend on technology alone. This process requires a comprehensive approach that offers accessible, fast, reliable and personalized services. The public sector in many countries is poorly prepared for such modernization. Traditional forms of regulation may not work and therefore require a paradigm shift in strategic thinking, legislation and regulation. Governments can respond by developing the necessary policies, services and regulations. This response will be in line with the objectives and enhance the role of education in achieving key goals. Services can be tailored to specific needs and specific target audiences, including authorities, business or civil society.

\section{References}

1. World Economic Forum, Digital Transformation Initiative In collaboration with Accenture. Digital Transformation Initiative (2017). Available at: http://reports.weforum.org/

2. S. Ziyadin, A. Beyzhanova, A. Orazymbetova, R. Yessenzhigitova, Proceedings of the 32nd International Business Information Management Association Conference, 30803084 (2018)

3. M. Kassen, Government Information Quarterly, 30(4), 508-513 (2013) DOI: https://doi.org/10.1016/j.giq.2013.05.012

4. S. P. Robertson, \& R. K. Vatrapu, Annual review of information science and $\begin{array}{llll}\text { technology, } & \mathbf{4 4}(1), & 317-364 & \text { (2010). }\end{array}$ https://doi.org/10.1002/aris.2010.1440440115

5. UNDESA, Benchmarking e-government: a global perspective (2001). Available at: https://publicadministration.un.org/

6. United Nations, World public sector report 2003: E-Government at the crossroads. United Nations Publications (2003). Available at: https://publicadministration.un.org/

7. United Nations, UN global e-government readiness report 2004: towards access for opportunity. United Nations Publications (2004). Available at: https://publicadministration.un.org/

8. D. L. Rabina, United Nations Global E-Government Readiness Report 2005: From EGovernment to E-Inclusion (Department of Economic and Social Affairs, New York, 2006). Available at: https://publicadministration.un.org/

9. United Nations. Division for Public Administration, \& Development Management, United Nations e-government survey 2008: From e-government to connected governance (Vol. 8). United Nations Publications (2008). Available at: https://publicadministration.un.org/

10. I. Peña-López, UN e-Government Survey 2014. E-Government for the Future We Want. United Nations Publications (2014). Available at: https://publicadministration.un.org/ 
11. OECD, E-Government for Better Government. OECD Publishing (2005). Available at: https://www.oecd.org/gov/digital-government/egovernmentforbettergovernment.htm

12. World Bank; Government of Vietnam, Digital Government and Open Data Readiness Assessment. World Bank, Washington, DC (2019). Available at: https://openknowledge.worldbank.org/handle/10986/32547

13. L. Sundberg, Safety science, 118, 22-32 (2019). DOI: https://doi.org/10.1016/j.ssci.2019.04.030

14. J. D. Twizeyimana, \& A. Andersson, Government information quarterly, 36(2), 167178 (2019). DOI: https://doi.org/10.1016/j.giq.2019.01.001

15. D. Liu, \& L. Carter, Proceedings of the 19th Annual International Conference on Digital Government Research: Governance in the Data Age, 1-6 (2018, May). DOI: https://doi.org/10.1145/3209281.3209340

16. E. Abu-Shanab, \& A. Al-Azzam, International Journal of Information Communication Technologies and Human Development (IJICTHD), 4(1), 39-51 (2012). DOI: https://doi.org/10.4018/jicthd.2012010103

17. G. P. Dias, Government Information Quarterly, 36(3), 400-411 (2019). DOI: https://doi.org/10.1016/j.giq.2019.05.008

18. T. Choi, \& S. M. Chandler, Government Information Quarterly, 37(1), 101416 (2020). DOI: https://doi.org/10.1016/j.giq.2019.101416

19. Y. Liang, G. Qi, X. Zhang, \& G. Li, Government Information Quarterly, 36(4), 101397 (2019). DOI: https://doi.org/10.1016/j.giq.2019.101397

20. I. Lindgren, C. Madsen, S. Hofmann, \& U. Melin, Government Information Quarterly, 36(3), 427-436 (2019). DOI: https://doi.org/10.1016/j.giq.2019.03.002

21. N. Faulkner, B. Jorgensen, \& G. Koufariotis, Government Information Quarterly, 36(1), 61-68 (2019). DOI: https://doi.org/10.1016/j.giq.2018.10.009

22. United Nations, E-Government Survey 2018. United Nations Publications (2018). Available at: $\quad$ https://www.unescap.org/sites/default/files/EGovernment\%20Survey\%202018_FINAL.pdf

23. K. Mukhtarova, S. Ziyadin, S. Kupeshova, \& R. Doszhan, Economic annals-XXI, (168), 38-43 (2017)

24. Z. Sayabek, D. Galiya, K. Zhanna, \& T. Asel, Proceedings of the 31th International Business Information Management Association Conference, 2065-2070 (2017)

25. S. Ziyadin, K. Malayev, G. Yessenova, \& A. Beyzhanova, E3S Web of Conferences, 135, 04025 (2019). DOI: https://doi.org/10.1051/e3sconf/201913504025

26. S. Ziyadin, \& N. Kabasheva, Public Administration Issues (5), 56-67 (2018)

27. Churilova, E., Salin, V., Shpakovskaya, E., \& Sitnikova, O. Journal of International Studies, 12(4). (2019).

28. Lawal, A. I., Omoju, O. E., Babajide, A. A., \& Asaleye, A. I. Journal of International Studies, 12(4). (2019).

29. Forlicz, M., \& Rólczyński, T. Journal of International Studies, 12(3), 198-211. (2019). 